August 2009

\title{
Wishful Thinking Will Not Stop Genocide: Suggestions for a More Realistic Strategy
}

Alan J. Kuperman

Follow this and additional works at: https://digitalcommons.usf.edu/gsp

\section{Recommended Citation}

Kuperman, Alan J. (2009) "Wishful Thinking Will Not Stop Genocide: Suggestions for a More Realistic Strategy," Genocide Studies and Prevention: An International Journal: Vol. 4: Iss. 2: Article 10.

Available at: https://digitalcommons.usf.edu/gsp/vol4/iss2/10

This Articles is brought to you for free and open access by the Open Access Journals at Digital Commons @ University of South Florida. It has been accepted for inclusion in Genocide Studies and Prevention: An International Journal by an authorized editor of Digital Commons @ University of South Florida. For more information, please contact digitalcommons@usf.edu. 


\title{
Wishful Thinking Will Not Stop Genocide: Suggestions for a More Realistic Strategy
}

\author{
Alan J. Kuperman \\ LBJ School of Public Affairs, University of Texas, Austin
}

Good intentions may be necessary, but they are not sufficient, to prevent genocide. Unfortunately, this renders the recent report of the Genocide Prevention Task Force, Preventing Genocide: A Blueprint for U.S. Policymakers (the Albright-Cohen Report), a recipe for failure. ${ }^{1}$ The co-chairs, former US secretaries of state and defense Madeleine Albright and William Cohen, obviously have good intentions, and they do offer several constructive reforms. Overall, however, the report ignores the most profound lessons of past failures, declines to make the hard choices on policy dilemmas, and neglects to call for the costly military reforms that could enable intervention to prevent future genocides. A more realistic assessment of these challenges gives rise to a very different set of recommendations than that found in the report.

The root of the problem is that the Albright-Cohen Report rests on six faulty, but largely unstated, assumptions: first, that the only substantial obstacle to stopping genocide is a lack of political will; second, that humanitarian intervention could be significantly improved by increased military planning and coordination with multilateral institutions; third, that the United States is often inhibited from intervening by financial considerations and by the belief that intervention must be all or nothing; fourth, that the political will for intervention can be fabricated by establishing new domestic and international institutions; fifth, that existing US diplomatic strategies to reduce genocidal violence are well conceived and thus could reduce genocidal violence if only they were backed by more funding and political will; and, sixth, that codifying humanitarian intervention as the automatic policy response to atrocities would reduce the amount of genocidal violence in the world. ${ }^{2}$ These faulty assumptions give rise to prescriptions that either are inadequate or could backfire.

\section{Flawed Assumptions}

Obviously, insufficient political will can be an obstacle to effective intervention. But it is not the only, or even the major, hindrance in many cases. Genocidal violence often is perpetrated too quickly for military intervention to prevent it, at least given the current make-up and positioning of potential intervention forces. In Rwanda, for example, most Tutsi victims of the 1994 genocide were killed in less than three weeks; in Croatia in 1995, the army ethnically cleansed the entire Serb population of the Krajina region in less than a week; in Kosovo in 1999, Serb forces ethnically cleansed nearly half of the ethnic Albanian population in two weeks; and in East Timor in 1999, Indonesian-backed militias destroyed the majority of infrastructure and displaced most of the population in about a week. The Albright-Cohen Report calls for a new genocide early-warning system, but that probably would not have made a difference in these cases because US forces typically require several weeks to deploy to such hot spots, even by air, owing to their enormous equipment needs. Moreover, the United

Alan J. Kuperman, "Wishful Thinking Will Not Stop Genocide: Suggestions for a More Realistic Strategy." Genocide Studies and Prevention 4, 2 (August 2009): 191-199. (C) 2009 Genocide Studies and Prevention. doi: 10.3138/gsp.4.2.191 
States already has early-warning systems, but such systems have difficulty in differentiating quickly between civil war and genocide.

The report's main military proposals to improve humanitarian interventionincreased Pentagon planning and coordination with multilateral institutions-are insufficient and potentially counterproductive. Although the report does a good job of delineating the potential military options to suppress genocidal violence (83), its main Pentagon reform proposal is merely to draft a new doctrine focused on countergenocide operations (87). The report neglects to call for a substantial overhaul of the equipping and basing of US forces, which would be politically divisive but necessary for any new doctrine to improve significantly the effectiveness of intervention. Rather than reconfiguring domestic forces, the report fancifully suggests that the lack of "rapid reinforcement capacity ... for UN forces could be remedied by creating a strategic reserve that would be drawn from countries contributing to UN missions" (91). Unfortunately, history demonstrates that advance international commitments of force to UN interventions-whether peacekeepers and armored vehicles for Rwanda or helicopters for Darfur-are not worth the paper they are written on. Moreover, by passing the buck to the United Nations, such initiatives undercut the prospects for quicker, more effective unilateral action.

In another vain attempt to conjure alternative intervention forces, the report embraces a US policy, initiated in the 1990s, to train indigenous African troops for peace operations (84-86). This initiative had a reasonable premise-that African states would be more willing than others to risk the lives of their troops to stop conflict on the continent-but it has faced practical obstacles. First, because of inadequate resources and some concern about unintended consequences, the United States has provided little, if any, weaponry or combat training. Accordingly, the participating African forces are prepared only for the permissive environment of peacekeeping after a conflict ends, as in Liberia in $2003 .{ }^{3}$ Second, the initiative has so far failed to pre-position heavy weapons, armored personnel carriers, or helicopters at African bases; as a result, in the event of a crisis, such equipment would have to be transported and joined up with intervention forces on an ad hoc basis, wasting precious time. Third, most training has been conducted only within national units, so that the few trained forces remain unprepared for the multinational coalition operations that would be necessary for any large-scale intervention. The African Union did recently establish the framework for an African Standby Force of five regional, multinational brigades. But this project, even after receiving some foreign assistance, is so woefully underfunded that it remains skeletal, adding little to the few high-quality national military units that already existed on the continent. ${ }^{4}$ In light of these shortfalls, an all-African force has little hope of enforcing peace in a situation such as Darfur any time soon.

The ultimate multilateral fantasy is the report's suggested reform of UN Security Council procedures:

The P-5 should agree that unless three permanent members were to agree to veto a given resolution, all five would abstain or support it. This should apply, in particular, to resolutions instituting sanctions and/or authorizing peace operations in situations when mass atrocities or genocide are imminent or underway. (106)

In other words, China and Russia should permit the United States, the United Kingdom, and France to decide by themselves when it is legal to violate another state's sovereignty. The report could have added a health advisory: don't hold your breath. 
No evidence is offered for the report's assertion that the United States has been inhibited from preventing genocide by the potential financial cost and the belief that intervention is an all-or-nothing proposition. "The question of who would pay the bill" (58), claims the report, blocked US intervention in Rwanda, Darfur, and Kenya. In reality, the United States dragged its feet in each case for political reasons: in Rwanda because of recent casualties in Somalia; in Darfur because US troops were overstretched in Iraq and Afghanistan and unable to contemplate another quagmire; and in Kenya, apparently, because the White House backed the candidate who stole the election. ${ }^{5}$ Creating a budget line for urgent intervention would not overcome such political obstacles.

The historical record also contradicts the report's assertion that, "in the past, the belief that little or nothing could be done to halt or reverse an escalating crisis, short of full-scale military intervention, has fatally undermined political will" (56). In reality, the United States has employed a range of flexible responses short of full-scale invasion by ground forces. In northern Iraq in 1991, the US military delivered humanitarian aid and imposed a no-fly zone. In Somalia in 1992, US Marines secured the delivery of relief aid. In Bosnia, between 1992 and 1995, the United States gradually escalated from aid flights, to a no-fly zone, to deterrent air strikes, to facilitating the arming and training of combatants, to bombing military installations. ${ }^{6}$ In Kosovo in 1999, the United States led NATO's strategic bombing of Yugoslavia. In Liberia in 2003, a small deployment of US Marines facilitated the departure of a brutal ruler and the end of a long-running civil war. ${ }^{7}$ Even during the Rwandan Genocide in 1994, the Pentagon planned a small-scale intervention on Rwanda's border to facilitate the escape of refugees, but the Clinton administration chose not to implement it until the fighting had stopped. In none of these cases was the United States deterred from responding flexibly by a belief that only "full-scale military intervention" with ground forces could do any good.

The report's proposal to create new domestic and international institutions could facilitate intervention, but only if there were also political will, which would not magically be created by those institutions. The institutional recommendations include spending $\$ 250$ million per year on conflict management, creating a new early-warning system, requiring policy reviews when warnings are received, establishing an Atrocities Prevention Committee to guide the response, and coordinating information sharing and intervention with international partners, including non-governmental organizations. These are fine suggestions, but they are neither sufficient to create the political will for intervention nor necessary when that political will already exists. The report claims that a lack of institutional capacity explains America's failure to stop genocide: "We know firsthand, for example, that the attention of senior policymakers was distracted from Rwanda in 1994 by other crises" (2). This excuse for non-intervention is demonstrably untrue and smacks of attempted self-exculpation by co-chair Albright, who at the time was ambassador to the United Nations. The Clinton administration knew immediately when violence broke out in Rwanda, figured out two weeks later that it was genocide, established an inter-agency task force that met daily, and yet still refused to deploy any forces to the region until three months later, after the genocide was over. ${ }^{8}$

\section{Preventive or Pyromaniac Diplomacy?}

The report assumes that current US strategies of preventive diplomacy are well designed and require only more funding and more political support in order to succeed. 
But evidence has mounted for nearly two decades that aspects of these strategies can exacerbate conflict and, therefore, should be modified or discarded. For example, the report calls for promoting democratization and enhancing "civil society ... [which] can be a bulwark against the spread of violence" (48). But scholars have repeatedly demonstrated that rapid democratization raises several-fold the risk of violence ${ }^{9}$ and that building intra-group civil society actually increases intergroup violence. ${ }^{10}$ Rwanda is exemplary: the infamous hate radio was the first station outside government hands, and the genocidal militias arose from the creation of new political parties-both developments ironically consistent with international pressure to expand democracy and civil society.

In keeping with recent US foreign policy, the report also advocates "threatening legal and moral accountability for violations of international law, especially in the era of the International Criminal Court [ICC] and ad hoc tribunals" (43). But there is no evidence that such international justice mechanisms produce any deterrent effect. ${ }^{11}$ To the contrary, there is plentiful evidence that ICC indictments in Uganda have inhibited the resolution of a conflict that threatens millions of innocent civilians in that country and in neighboring Sudan and the Democratic Republic of Congo. The indicted rebel leader Joseph Kony offered to surrender if the ICC indictment were dropped in favor of local justice mechanisms, to which Uganda's government agreed, but the ICC refused, thereby perpetuating the violence. ${ }^{12}$ The report, to its credit, notes that "policymakers should not dismiss the potential benefits of rewarding 'bad people' for 'good behavior'" (70). But it then ignores its own advice by endorsing uncompromising international justice mechanisms such as the ICC, concluding that "the potential benefits do indeed outweigh the costs" (103). This conclusion is hardly convincing, given that the benefits have yet to be identified while the costs already include thousands of innocent civilians lying in unmarked graves.

Equally disturbing is that the report advocates international sanctions to compel states to share power with opposition groups, without acknowledging or addressing the fact that such pressure has backfired disastrously in several recent cases. ${ }^{13}$ In Rwanda in the early 1990s, the international community withheld vital aid to successfully force the Hutu majority regime to sign an agreement to hand power to invading Tutsi rebels. But hard-line Hutu elements felt so threatened by the prospect of domination by the historically oppressive Tutsi, especially after the Hutu president was assassinated, that they instead perpetrated a final solution to kill all Tutsi. ${ }^{14}$ Similarly, in East Timor in 1999, international sanctions successfully compelled Indonesia to hold an independence referendum, but Indonesian-backed militias so feared the prospect of losing power and facing retribution that they rampaged in a vain attempt to retain control. ${ }^{15}$ The Albright-Cohen Report simplistically asserts that sanctions "may help deter or dissuade... [states] from committing atrocities" and that "aid conditionality may be used to improve the behavior of regimes" (42-43). But history demonstrates that attempting to use sanctions to compel a regime to hand over power or territory to its mortal enemy can backfire catastrophically-serving not as preventive but as "pyromaniac" diplomacy. ${ }^{16}$

The report also fails to recognize a crucial nuance- that international pressure can have drastically different consequences depending on whether it is used to support violent or non-violent domestic protest groups. When international sticks and carrots are used to aid peaceful resistance movements, the target state is more likely to make concessions toward freedom and equality. By contrast, when international pressure seeks to coerce a state to concede to rebels, the militants typically are emboldened 
by the perceived diplomatic support, which compels the state to intensify its counterinsurgency, thereby exacerbating humanitarian suffering and reducing the prospects for democratization. ${ }^{17}$ Ironically, the report lists "nonviolent protest" as associated with "increased risk of genocide or mass atrocities" (25). This may be true compared to a situation of no protest, but it is exactly wrong in relation to the relevant comparison: violent protest.

This underscores the signal shortcoming of the report: a failure to appreciate how institutionalizing a humanitarian response can inadvertently backfire by creating more humanitarian suffering, a dynamic akin to "moral hazard," as I and others have documented over the last decade. ${ }^{18}$ Since at least 1945 , most genocidal violence has been state retaliation against perceived civilian supporters of rebellion. Humanitarian intervention aims to protect these civilians, but, in so doing, it often rewards the rebels as well, by enabling them to attain political objectives of autonomy or independence, as in Kosovo or Iraqi Kurdistan. The recent practice of humanitarian intervention thus creates a perverse incentive for rebellion by militants who cannot protect their own civilians against anticipated state retaliation-as in Bosnia, Kosovo, and Darfur. Counterintuitive as this conclusion may seem, institutionalizing humanitarian intervention thus causes some genocidal violence that would not otherwise occur.

The report alludes to this moral-hazard problem once, asking, "Will overt support to the threatened communities reduce their vulnerability or embolden them to take actions that will only escalate the problem?" (57-58). But the authors do not explain this conundrum, nor discuss what to do about it. Indeed, the report never uses the term "moral hazard"; it only once employs the related term "morally hazardous" (70) and, ironically, does so incorrectly. More troublingly, the report endorses a litany of "targeted measures" (66)_including economic sanctions, arms embargoes, covert assistance to rebels, and military intervention-all of which would exacerbate the moral-hazard problem. More enlightened intervention measures could mitigate this perverse dynamic, as I detail elsewhere and summarize below, ${ }^{19}$ but the report offers no such recommendations.

\section{A More Realistic and Effective Strategy}

The Albright-Cohen Report's stated goal of reducing genocidal violence may be achievable by embracing a different, more realistic set of policy recommendations. These alternative proposals are based on two key insights. First, since most genocidal violence arises as a state response to rebellion, an enlightened intervention policy should aim to deter both rebellion and overreaction by states, thereby reducing the need for humanitarian military intervention to a level within the capacity of potential interveners. ${ }^{20}$ Second, because genocidal violence can be perpetrated very quickly if and when diplomacy fails, a main determinant of the number of lives saved is the speed of deployment; therefore, military reforms should focus on stationing and structuring intervention forces for rapid reaction.

Five reforms of intervention policy could help reduce moral hazard and, thus, the amount of genocidal violence confronting potential interveners. The first reform is the most important: the international community should refuse to intervene in any waydiplomatic, economic, or military - to help sub-state rebels unless state retaliation is grossly disproportionate. This would discourage militants within vulnerable sub-state groups from launching provocative rebellions that recklessly endanger civilians in hopes of garnering foreign intervention. At the same time, by retaining the 
intervention option for cases of disproportionate retaliation, this reform also would discourage states from responding to rebellion by intentionally harming civilians. All sides in civil conflicts would thus have incentives for less violent action.

Second, when interveners in a civil conflict aim to deliver purely humanitarian aid (food, water, sanitation, shelter, and medical care), they should do so in ways that minimize the help to rebels. Typically, rebels benefit from such deliveries by intercepting aid convoys or by transforming refugee and internally displaced persons (IDP) camps into training and recruitment centers. To prevent this, interveners should provide military escort for aid convoys and deploy well-trained troops or police to secure the perimeters of camps to prevent the entry of weapons.

Third, potential interveners should expend substantial resources to persuade states to address the legitimate grievances of nonviolent domestic groups. In combination with the first reform, this would undo the perverse incentive that arises from current intervention practices, which effectively ignore nonviolent groups because they do not provoke state retaliation but reward militants by intervening in ways that benefit them, thereby promoting violence. Rather than punishing states when they defend themselves against armed challenges, interveners should provide states with incentives to address nonviolent demands in hopes of averting such rebellion.

Fourth, interveners should not attempt to coerce states to hand over territory or authority to domestic opposition groups unless the interveners first take steps to reduce the danger of a deadly backlash. Failure to do so can have catastrophic consequences, as exemplified in Bosnia, Rwanda, Kosovo, and East Timor. ${ }^{21}$ In each of these cases, international coercion backfired when the state resisted and retaliated against domestic civilians, whom it perceived as allies of the enemy. At least three measures should be employed to reduce this risk. Interveners should offer oppressive rulers "golden parachutes," including asylum and retention of wealth, if they leave office peacefully. Likewise, interveners should guarantee a continued share of power to existing elites, who would then have more to gain from peace than from attempting a desperate final solution. Because these first two steps may prove inadequate, interveners also should deploy peacekeepers prior to any coerced handover of power, such as an independence referendum. If interveners are unwilling to take these precautions, they should refrain from coercing regime change, to avoid magnifying the risks of genocidal violence.

Fifth, interveners should refrain from falsely claiming humanitarian motives for interventions that are driven primarily by other objectives, such as securing resources, fighting terrorism, or preventing nuclear proliferation. This is because each ostensible "humanitarian" intervention increases the expectations of sub-state groups elsewhere that they too will benefit from intervention if they rebel and provoke a humanitarian emergency. A false justification for intervention in one case may thus inadvertently promote civil war in others. In situations such as Iraq in 2003, interveners obviously have incentive to claim falsely, or to exaggerate, their altruistic motivation. Before doing so, however, they should weigh seriously the potential unintended consequences.

\section{Military Reforms}

Regardless of any policy reforms to reduce the incidence of genocidal violence, in some cases civilians will still be so threatened that only military intervention can save them. In light of the speed of violence in many recent cases, potential interveners should concentrate on two military reforms that could get forces into the field more quickly. 
First, interveners should modify some power-projection forces so that they can deploy faster. Currently, each planeload of US troops requires at least ten planeloads of equipment before the troops can operate effectively, which slows deployment to a crawl because of limited airfield capacity. Lighter forces, with fewer heavy weapons and less armor, would require fewer cargo flights, enabling them to arrive sooner and save more lives. Of course, shedding protective armor and weaponry could also increase casualties, as US forces learned in Iraq after they transitioned from major combat operations to peacekeeping in $2003 .^{22}$ Such a trade-off cannot be made lightly.

The second military reform is to pre-position forces-or, at least, their heavy equipment-at forward bases closer to where they are most likely to be needed for humanitarian intervention, such as in Africa. Interventions could be launched from these bases using small cargo aircraft, which are both more plentiful than wide-body intercontinental airlifters and better able to land at rudimentary African airfields. The tactical cargo aircraft could make several round-trips per day to a conflict zone from forward bases, rather than one trip every few days from distant US or European bases, and thus sharply reduce deployment time-from weeks to days. One potential hurdle is that many African states oppose foreign military bases as tantamount to neocolonialism, as demonstrated by the Pentagon's recent difficulty in establishing a proposed continental headquarters for its new Africa Command (AFRICOM). ${ }^{23}$ But such resistance could be overcome by offering sufficient incentives. The real obstacle is that the world's major powers, including the United States, have proved unwilling to make significant military investments except to promote traditional national interests.

\section{The Challenge Ahead}

The Albright-Cohen Report's recommendations cannot achieve their stated goal and therefore need to be supplemented. The proposals I have made here are more realistic, requiring less frequent military intervention, yet could do more to reduce genocidal violence. Admittedly, this alternative reform package would also face significant political hurdles. The good news is that the United States has by far the world's greatest potential for humanitarian intervention-military, economic, and diplomatic-to prevent genocide. If the Obama administration is willing to learn from history and modify US intervention policy and forces accordingly, the United States can begin to fulfill the laudable ambitions of the Genocide Prevention Task Force.

\section{Notes}

1. Madeleine K. Albright and William S. Cohen, chairs, Preventing Genocide: A Blueprint for U.S. Policymakers (Washington, DC: Genocide Prevention Task Force, 2008), http://www.usip.org/genocide_taskforce/report.html (accessed 12 June 2009), xxi. Subsequent references appear parenthetically in the text.

2. In Alan J. Kuperman, "The Moral Hazard of Humanitarian Intervention: Lessons from the Balkans," International Studies Quarterly 52 (2008): 49-80, I define "humanitarian intervention" broadly as "any international action that is primarily motivated by the humanitarian desire to protect civilian targets of state violence. The spectrum of such action is wide, ranging from low-cost measures that respect traditional state sovereignty to high-cost ones that impinge on it. This includes the following: rhetorical condemnation; threats or imposition of economic sanctions; recognizing the independence of secessionist entities; air strikes on military or economic assets; military assistance to or coordination with rebels perceived as defending at-risk civilians; consensual deployment of peacekeepers; and non-consensual deployment of troops for peace enforcement." 
The Albright-Cohen Report calls for an automatic policy review in response to early warning of violence $(31)$ and lists a range of potential responses $(61,66)$ similar to that in my definition.

3. Ian Rudge, "Operation Focus Relief: A Program Evaluation" (unpublished manuscript, LBJ School of Public Affairs, University of Texas at Austin, 14 December 2005).

4. Benedikt Franke, "Enabling a Continent to Help Itself: U.S. Military Capacity Building and Africa's Emerging Security Architecture," Strategic Insights 6, no. 1 (2007), http:// www.cc..nps.navy.mil/si/2007/Jan/frankeJan07.asp (accessed 12 June 2009).

5. Mike McIntire and Jeffrey Gettleman, "A Chaotic Kenya Vote and a Secret U.S. Exit Poll," New York Times, 31 January 2009, A1.

6. Alan J. Kuperman, "Humanitarian Intervention," in Human Rights: Politics and Practice, ed. Michael Goodhart, 334-53 (Oxford: Oxford University Press, 2009).

7. Alan J. Kuperman, "A Small Intervention: Lessons from Liberia 2003," in Naval Peacekeeping and Humanitarian Operations: Stability from the Sea, ed. Jim Wirtz and Jeff Larsen, 153-69 (Abingdon, UK: Routledge, 2009).

8. Alan J. Kuperman, The Limits of Humanitarian Intervention: Genocide in Rwanda (Washington, DC: Brookings Institution Press, 2001).

9. Edward D. Mansfield and Jack Snyder, "Democratization and War," Foreign Affairs 74 (1995): 79-97. The Albright-Cohen Report does note that "the introduction of electoral competition into divided societies can heighten the prospect of conflict" (45), but, remarkably, this observation does not temper the report's enthusiasm for promoting democratization to reduce conflict.

10. Ashutosh Varshney, "Ethnic Conflict and Civil Society: India and Beyond," World Politics 53 (2001): 362-98.

11. Helena Cobban, "Think Again: International Courts," Foreign Policy 153 (2006): 22-28.

12. "Rebels and Ugandan Government Agree to Terms of Prosecutions of War Crimes," New York Times, 20 February 2008.

13. Alan J. Kuperman, "Ripeness Revisited: The Perils of Muscular Mediation," in Conflict Management and Africa: Negotiation, Mediation, and Politics, ed. Terrence Lyons and Gilbert Khadiagala, 9-21 (Abingdon, UK: Routledge, 2008).

14. Alan J. Kuperman, "The Other Lesson of Rwanda: Mediators Sometimes Do More Damage Than Good," SAIS Review 16 (1996): 221-40.

15. Alan J. Kuperman, "Once Again, Peacekeepers Arrive Too Late," Wall Street Journal, 21 September 1999.

16. The term "pyromaniac diplomacy" comes from Ahmedou Ould Abdallah and Stephen Smith, La Diplomatie Pyromane: Burundi, Rwanda, Somalie, Bosnie (Paris: CalmannLévy, 1996).

17. Adrian Karatnycky and Peter Ackerman, How Freedom Is Won: From Civic Resistance to Durable Democracy (Washington, DC: Freedom House, 2005). The study has methodological flaws, but it does suggest that nonviolent resistance movements lead to more democratic outcomes.

18. Kuperman, "The Moral Hazard"; Alan J. Kuperman, "Strategic Victimhood in Sudan," New York Times, 31 May 2006, 19; Timothy W. Crawford and Alan J. Kuperman, eds., Gambling on Humanitarian Intervention: Moral Hazard, Rebellion and Civil War (New York: Routledge, 2006); Alan J. Kuperman, "Suicidal Rebellions and the Moral Hazard of Humanitarian Intervention," Ethnopolitics 4 (2005): 149-73; Alan J. Kuperman, "Humanitarian Hazard: Revisiting Doctrines of Intervention," Harvard International Review 26 (2004): 64-68; Alan J. Kuperman, "Transnational Causes of Genocide: Or How the West Inadvertently Exacerbates Ethnic Conflict," in Yugoslavia Unraveled: Sovereignty, Self-Determination, Intervention, ed. Raju G.C. Thomas, 55-85 (Lanham, MD: Lexington Books, 2003); Alan J. Kuperman, "False Hope Abroad: Promises to Intervene Often Bring Bloodshed," Washington Post, 14 June 1998.

19. Alan J. Kuperman, "Mitigating the Moral Hazard of Humanitarian Intervention: Lessons from Economics," Global Governance 14 (2008): 219-40; Alan J. Kuperman, 
"Rethinking the Responsibility to Protect," Whitehead Journal of Diplomacy and International Relations 10 (2009): 33-43.

20. The Albright-Cohen Report aptly observes that "preventing or ending violent conflict will have a direct and positive impact on preventing genocide or mass atrocities" (38).

Unfortunately, its recommendations could increase such violent conflict.

21. Kuperman, "Ripeness Revisited"; Kuperman, "Once Again."

22. R. Jeffrey Smith, "Study Faults Army Vehicle," Washington Post, 31 March 2005, A1.

23. Peter Fabricius, "SADC Shuns Spectre of US Africom Plans," Sunday Independent (South Africa), 15 July 2007, 3; Gideon Nkala, "We Are Damned If We Do, Damned If We Don't," The Reporter (Botswana), 27 June 2008. 